\title{
МОДЕРНІЗАЦІЯ ВИЩОЇ МЕДИЧНОЇ ОСВІТИ В КОНТЕКСТІ БОЛОНСЬКОЇ КОНВЕНЦІї - ІДЕЯ, МЕТА ТА РЕАЛІЇ
}

\author{
В. М. Мороз, Ю. Й. Гумінський, Л. В. Фоміна, Т. Л. Полеся, О. І. Башинська \\ Вінницький національний медичний університет імені М. І. Пирогова
}

\section{MODERNIZATION OF HIGHER MEDICAL EDUCATION IN CONTEXT OF BOLOGNA CONVENTION - IDEA, OBJECT, REALITIES}

\author{
V. M. Moroz, Yu. Y. Huminskyi, L. V. Fomina, T. L. Polesya, O. I. Bashynska \\ Vinnytsia National Medical University by M. I. Pyrohov
}

\begin{abstract}
У зв'язку з європейською інтеграцією України та реформою вищої освіти у вищих медичних навчальних закладах 32005 року впроваджується кредитно-модульна система навчання у світлі Болонської конвенції. Впродовж шестирічного досвіду були виявлені протиріччя між ідеями Болонських угод та їх реалізацісю. У зв'язку з коадаптацією національної системи навчання до європейських стандартів проведений аналіз якості вищої медичної освіти під час реалізації положень кредитно-модульної системи навчання 3 врахуванням національних особливостей.

Reformation of the higher education and integration of Ukraine to Europe requires the introduction of credit-modular system of organization to the Medical universities by Bologna convention. Due sixth year experiment there were determined differences between ideas by Bologna declarations and their realizations. Coadaptation national higher medical education to the European standards analyzed quality of the higher medical education due realization of the basis of credit-modular system of organization of educational process with national peculiarities.
\end{abstract}

Вступ. Інтеграція України у Європу передбачає реформування вищої освіти та входження в Європейський освітній простір. Процес євроінтеграції вимагає нових підходів до організації навчального процесу у вищих навчальних закладах, що й було задекларовано Україною у підписаній Болонській конвенції та полягає у запровадженні інноваційних технологій навчання [1]. Ідея реформування медичної вищої освіти полягає в адаптації національної системи вищої освіти до європейських стандартів та забезпечення якості підготовки фахівців на рівні міжнародних вимог. Метою реформування вищої освіти є створення уніфікованих критеріїв, методологій та систем контролю, а також взаємовизнання дипломів про вищу освіту, сприяння мобільності студентів [2]. Кінцевою метою впровадження інноваційних технологій $€$ конкурентоспроможність українських освітянських кваліфікацій на європейському ринку праці, визнання загальноприйнятої системи освітньо-кваліфікаційних ступенів, впровадження стандартизованого додатка до диплома.

Основна частина. Болонська конвенція - документ, головною ідеєю якої є стандартизація підходів до організації навчального процесу та функціонування вищої школи в Свропі. Головна мета - гармоніза- ція національних освітніх систем вищої освіти в країнах Європи з метою підвищення конкурентоспроможності ВНЗ Старого світу порівняно з університетами інших регіонів планети (в тому числі США) [1-2]. Відповідно до основних положень Болонської декларації передбачається уніфікована для всіх країн система вчених ступенів (бакалавра, магістра, доктора філософії), залікова система накопичення кредитів (кредити можна отримувати порціями в різних вузах країн-учасниць), навчання протягом усього життя, автономність вузів, мобільність студентів та викладачів та ін. [3]. Сама ідея реалізації даних рекомендацій сприяє підвищенню престижності європейської вищої освіти; створенню єдиного простору вищої освіти із забезпеченням мобільності студентів різних країн та їх працевлаштуванням; зміцненню науковотехнічного, соціального та інтелектуального потенціалу Європи; досягненню сумісності систем вищої освіти; надає студентам право для вивчення вибору дисциплін; підвищує якість освіти в країнах-учасницях; забезпечує конкурентоспроможність європейських університетів [4]. Згідно з наказами $\mathrm{MOH}$ та MO3 України у Вінницькому національному медичному університеті ім. М. І. Пирогова $32005-2006$ н. p. впроваджено кредитно-модульну систему навчання.

(ㄱ В. М. Мороз, Ю. Й. Гумінський, Л. В. Фоміна та ін. 
У 2011 році вищі медичні навчальні заклади України завершили повний цикл виконання рекомендацій Болонської конвенції. Шестирічний досвід впровадження кредитно-модульної системи надав змогу проаналізувати результати коадаптації національної та кредитно-модульної систем навчання. Не відмовляючись від ідеї Болонського процесу в цілому, є сенс зупинитися на дискомфортних та суперечливих моментах “українського” варіанта-основних принципів Болонської конвенції та поєднання їх з реаліями національної медичної освіти.

Проведений аналіз результатів навчання при організації навчального процесу за кредитно-модульною системою висвітлив деякі протиріччя та недоліки. Відзначається певна дисгармонійність співвідношення різновидів роботи студента (аудиторної та самостійної роботи) - відбулося перенесення центру тяжіння на СРС, що відображено у формальному зменшенні кількості аудиторних годин у типовій програмі на дисципліну. Збільшено інформаційне навантаження на студента та викладача. У зв’язку з відсутністю університетської клініки не враховується специфічність навчання студента - майбутнього лікаря на клінічних базах міських лікарень. Проблематичне питання постає щодо самостійності вивчення клінічних дисциплін - можливості самостійного опанування студентом умінь та практичних професійних умінь та навичок.

Найбільш істотно впливають на якість вищої освіти такі аспекти освітньої діяльності, як падіння престижу статусу викладача ВН3, що обумовлено збільшенням в 3-4 рази аудиторного навантаження та меншим рівнем заробітної плати (в 10-30 разів) у порівнянні $з$ закордонними колегами, хоча якість підготовки викладачів і наукових співробітників вузів гарантується високою академічною кваліфікацією.

Використання тестової системи оцінки знань значно спрощує процес перевірки та контролю знань студентів та, можливо, і має на меті забезпечення стандартів якості вищої освіти, але ж на практиці використання тестової системи контролю призводить до формування обмеженого мислення студентів, які замість самостійного пошуку вирішення проблем здатні тільки вибрати необхідне рішення із 4-5 запропонованих готових тестів. Система тестового контролю не примушує студента думати, що найбільш негативно впливає на рівень знань і умінь. Майбутні випускники не здатні знаходити адекватні та креативні рішення, а медицина цього вимагає на кожному кроці (при спілкуванні з хворими, дітьми, батьками, колегами).
Проблема підготовки лікарів при переході на сімейну та страхову медицину висуває високі вимоги щодо рівня підготовки спеціалістів. Сімейний лікар повинен оволодіти дуже великим об'ємом знань, вміти працювати 3 цілим рядом обладнання тощо. Був би доцільним розумний діючий закон про університетські клінічні бази (в ідеальному варіанті-університетські клініки). Щодо дистанційного та самостійного навчання, яке базується на широкому використанні комп'ютерних мереж, постає питання - чи може бути повноцінним спеціалістом студент, що пройшов курс дистанційного навчання в медицині, від безпосередньої роботи з об'єктами навчання?

Потрібно зазначити, що не всі європейські вузи підписали Болонську угоду, тому що елітні вищі навчальні заклади не потребують реклами. Медична освіта є найбільш фінансово навантаженою, що обумовлено утриманням і розвитком складного навчально-наукового обладнання, проведенням комплексних наукових досліджень і експериментів. В цілому елітні ВНЗ складають “старі” класичні університети світу, які мають свої наукові і освітні традиціі. Вони відрізняються орієнтацією на науково-дослідницьку діяльність і підготовку спеціалістів, здатних проводити фундаментальні і прикладні аналітичні дослідження. Тому в нових умовах слід опікуватись підсиленням цього компонента наукової діяльності.

Не менш важливим є питання про відповідність традиційних оцінок за 4-бальною національною шкалою та 7-бальною рейтинговою шкалою ECTS. Вони не збігаються, а шлях існування двох шкал (національна - для призначення стипендіi) не сприяє виробленню психології “відмінника” у студента та привела до бюрократизації рейтингової оцінки, як кінцевих результатів оцінювання знань студента. Для деканатів збільшилася кількість заповнення звітної документації для проведення рейтингу (у 3-4 рази), а як наслідок - й помилок. За існуючими нормативними правилами, при визначенні оцінки “F”, як незадовільної, університет має відраховувати щорічно 10 \% студентів за академічну неуспішність (наприклад, 3 1000 першокурсників дипломи отримають-523), що неприйнятно для планів на держзамовлення щодо прийому та випуску фахівців. Складається враження, що студенти навчаються не заради знань, а заради рейтингу або заохочувальних балів.

Перескладання академічної заборгованості в Тимчасовому положенні про організацію навчального процесу за кредитно-модульною системою дозволяється не більш ніж двічі. Але в реальному житті часто студенти не спроможні перескласти підсум- 
ковий модульний контроль і більше разів. 3 одного боку, це може виглядати як позитив (студент буде перескладати модуль, вивчаючи матеріал додатково, поки не відповість на достатньому рівні), але таке явище дискримінує іншого студента, що склав модуль вчасно. Врешті-решт обидва отримають однакову рейтингову оцінку. Такий підхід замість стимулювання навчання призводить до позиції безініціативності і байдужості до навчання студентів. Слід зазначити, що збільшується академічне навантаження викладачів без відповідного заохочення (зважаючи на частоту призначених перескладань на кафедpax). Кількість перескладань студентами академічної заборгованості на кафедрах призводить іноді до "вибуху лояльності" в екзаменаторів, що ніяк не сприяє підвищенню рівня вищої освіти.

Оцінювання знань за кредитно-модульною системою навчання не стимулює студента до усвідомлення структури, змісту, логіки, розуміння програмного матеріалу з дисциплін, тому що підвищена питома вага поточного оцінювання (60\%), а підсумковим знанням 3 модуля відводиться лише $40 \%$ від загальної суми балів. Скасування іспиту взагалі призводить до неможливості перевірки інтегрованих, системних знань студента. Оцінка знань частинами не залишає у студента цілісного уявлення про відповідний предмет та не сприяє отриманню довгострокових системних знань. Модульна (дискретна) система роботи, тестування та оцінювання працює лише на накопичення окремих знань, а не на розуміння суті предмета. В навчальному процесі для студента іноді немає місця для реалізації неординарних можливостей, створення креативного мислення і генерації власних думок.

Відбувається зниження рейтингу такої посади, як завідувач кафедри, акцент робиться на пріоритетне значення викладача, на практичних заняттях асистентом оцінюється $60 \%$ знань студента. Завідувач кафедри та доценти $\epsilon$ екзаменаторами, що оцінюють 40 \% знань студента. Скасування іспиту - скасування системи колегіального контролю та контролю завідувача.

Менталітет національної вищої освіти та кредитно-модульна рейтингова організація навчального процесу мають кардинальні відмінності. Традиційна система навчання - це насамперед відносини між студентами, де велику роль відіграє студентська група. Єдина програма, спільна робота робить групу єдиним соціальним організмом, який забезпечує взаємну підтримку, взаємодопомогу і виховний вплив ко- лективу. Це дає студенту навички колегіальності, що має велике значення в професії лікаря. А кредитнорейтингова система полягає у змаганні в рейтингах, іноді не дуже дружніх. Мабуть, тому середній за здібностями випускник нашого ВН3, працюючи в колективі, виявляється на голову вище, ніж його західний одноліток приблизно ж таких потенційних здібностей.

У відношенні до елективних курсів модульна система ("кредитна система") передбачає опанування їх за самостійним вибором студента. Годинна завантаженість навчальних програм не дозволяє зробити даний вибір. Бракує також викладачів та часу у студентів, тому вибір без усвідомлення (базової освіти) $\epsilon$ некоректним та алогічним. Даний варіант адекватний для післядипломної освіти.

Приймаючи угоду Болонської конвенції, ми не повинні втрачати свого неповторного досвіду - логічної, поступової та практично спрямованої системи. Доказом позитивного досвіду та високого рейтингу даної системи $є$ навчання у медичних ВНЗ іноземних громадян.

Висновки. Існуюча система освіти, як в Свропі, так і в Україні, потребує радикального реформування. Це означає, що не потрібно бездумно копіювати методи організації навчального процесу, набагато цінніше виявляється критична оцінка їх реального змісту і усвідомлення необхідності пошуку альтернативних варіантів організації навчального процесу. В такому випадку інноваційні системи організації навчального процесу у світлі Болонських угод дійсно будуть на користь вітчизняній вищій освіті, яка може послужити поштовхом до формування активного незалежного руху до по-справжньому гідної вищої медичної освіти. За своєю сутністю [5] Болонський процес - це нова концепція реформування вищої медичної школи, яка має поєднати національні надбання та інноваційні європейські технології щодо входження до єдиного освітнього простору. Важливо, щоб процес інтеграції вітчизняної і європейської систем підготовки лікарів здійснювався шляхом зближення систем освіти, через гармонійне поєднання вітчизняного i міжнародного досвіду [1]. Кожна країна, реформуючи свою освіту, має повне право враховувати специфіку як своєї національної системи освіти, так і медичної освіти в цілому. Всі положення Болонської конвенції мають рекомендуючий характер. В країнах Європи їх розглядають не як привід відмовитись від своєї національної системи освіти, а для того, щоб взяти з неї те, що буде слугувати її покращенню. 


\section{Література}

1. Визначення критеріїв якості в системі безперервного професійного розвитку лікарів та провізорів на основі концепції кредитів / Ю. В. Вороненко, А. М. Сердюк [та ін.] // Медична освіта. - 2007. - № 3.-С. 11-15.

2. Комюніке Конференції міністрів європейських країн, відповідальних за сферу вищої освіти (Лондон, 16-19 травня 2007 року). - К., 2008. - Кн. 4 : Основні засади розвитку вищої освіти України. - С. 24-30.

3. Вища медична освіта і Болонський процес : навч.- метод. та інф.-довідк. матеріали наради-семінару для наук.пед. працівників, аспірантів, магістрів (17-19 січня 2005 р.).
Частина I. - К., 2005. - С. 112-115.

4. Байденко В. И. Болонский процесс : структурная реформа высшего образования Европы / В. И. Байденко. [3-е изд.]. - М. : Исследовательский центр проблем качества подготовки специалистов, Российский Новый Университет, 2003.- С. 28-30.

5. Болонский процесс : нарастающая динамика и многообразие (документы международных форумов и мнения европейских экспертов). - М. : Исследовательский центр проблем качества подготовки специалистов, 2002. - С. 231234. 